\title{
Sustainable Methods of Addressing Challenges Facing Small Holder Tea Sector in Kenya: A Supply Chain Management Approach
}

\author{
Elias Kiarie Kagira ${ }^{1}$, Sarah Wambui Kimani ${ }^{2}$ \& Kagwathi Stephen Githii ${ }^{3}$ \\ ${ }^{1}$ Department of Business Administration, Africa Nazarene University, Nairobi, Kenya \\ ${ }^{2}$ The Catholic University of Eastern Africa, Nairobi, Kenya \\ ${ }^{3}$ Department of Business Administration, Africa Nazarene University, Kenya \\ Correspondence: Elias Kiarie Kagira, Department of Business Administration, Africa Nazarene University, PO \\ Box 53067, Nairobi, Kenya. Tel: 254-713-209-606. E-mail: ekiarie@anu.ac.ke or kkagira@yahoo.com
}

Received: December 21, 2011 Accepted: February 29, 2012 Online Published: May 24, 2012

doi:10.5539/jms.v2n2p75 URL: http://dx.doi.org/10.5539/jms.v2n2p75

\begin{abstract}
This Conceptual paper addresses the challenges facing the small holder tea sector in Kenya. It provides background information about tea growing in Kenya, its export performance, and organizational structure. It then categorizes the main challenges into five and provides some solutions to the challenges, borrowing from some supply chain management practices to culminate into competitive strategies. In the face of declining and shifting competitiveness of the small holder tea sector in Kenya, this paper identifies the special role of supplier and customer relationships, value addition, information technology, information sharing, flexibility in internal operations/processes, upgrading of tea seedlings, proper coordination, institutionalization, policy reforms, training, monitoring marketing environment, strategic decisions, irrigation, venturing in new markets through partnership, and civil society involvement as competitive supply chain strategies.
\end{abstract}

Keywords: small holder tea, challenges, organizational structure, sustainability, supply chain management

\section{Introduction}

Agriculture is the main sector in the Kenyan economy. Export Processing Zones Authority (EPZA, 2005), has noted that the sector accounts for about 24\% of Kenya's Gross Domestic Product. Further, an estimated 75\% of the population depends on the sector either directly or indirectly (EPZA, 2005). Agriculture is the largest provider of foreign exchange through export earnings of agricultural products. Kenya's main cash crops are tea, coffee, flowers, fruits, pyrethrum, tobacco, sugar, cotton, sisal, and wattle. In 2003, tea, coffee and horticultural products contributed fifty five percent of exports revenue. It has been noted that good agricultural performance in the country translates into measurable improvements in the quality of life (Kimenyi, 2002).

The purpose of this paper was to highlight the state of the art of the Kenyan small holder tea sector with an aim of addressing the challenges facing the sector in more sustainable ways. Many studies done on tea sector have concentrated on tea plantations and have largely ignored the small holder tea sector.

\section{Tea Industry in Kenya}

The tea (Camelia sinensis) history in Kenya can be traced back to 1903 when G.W.L, Caine, a European settler introduced the first seedlings from India and planted them in Limuru near Nairobi (Tea Board of Kenya, 2010). Tea is defined in the Tea Act 1950, as plant Camelia Sinensis. The cultivation of Tea for commercial purposes in Kenya commenced in 1924. The early settlers and colonial government restricted tea growing to large scale farmers' and multinational companies because they wanted to maintain high quality. Africans were restricted from growing the crop. On the attainment of independence in 1963, the government passed various land reform bills that had far reaching implications on agriculture in the country. For instance, tea growing was made open to the local farmers. Since then tea growing is wide-spread in Kenya and it is a major economic activity of many small holder farmers. Kenya currently prides itself as one of the world's leading black tea producers.

Tea sector in Kenya operates under the Ministry of Agriculture which provides technical and policy guidance. The sector is well thought-out right from the apex regulatory body, the Tea Board of Kenya, the Tea Research Foundation of Kenya, through the producers, tea processing factories, the trade and blending and packing 
enterprises (Tea Board of Kenya, 2011). The current existing market outlets for tea are: Mombasa auction accounting for $75 \%$, Kenya Tea Packers (7\%), direct sales in overseas and local markets (15\%) while factory door sales accounts for 3\% (Tea Board of Kenya, 2011).

The tea sub sector in Kenya is wholly liberalized and the marketing of tea is independently carried out by trade members (EPZA, 2005). However, the Tea Board of Kenya as the apex body in the sector plays a major responsibility in growing the traditional markets for Kenyan tea, as well as diversification into new markets.

\subsection{Tea Growing in Kenya}

Tea industry in Kenya operates under Tea Act (Cap 343) and Agricultural Act (Cap 318) of Kenyan laws. The tea growing industry in Kenya is unique because it has two separate sectors; large scale sector (plantation) and the small scale sector. The plantation sector is owned by large scale tea producers and companies, mostly multinationals such as Unilever Tea while the small holder sector is owned by local small scale growers. The small holder sector has more than half a million tea growers scattered throughout Kenya, who sell their tea through small holder tea factories that are run by Kenya Tea Development Agency Ltd (Tea Board of Kenya, 2011).

According to Tea Board of Kenya (2010), Kenya is the third principal producer and the primary exporter of tea in the world at twenty three percent. Kenyan tea is grown in the highlands $(1500 \mathrm{~m}-2700 \mathrm{~m})$ with alluvial soils. This gives tea a distinctive quality and taste. Tea growing in Kenya involves no application of pesticides and chemicals. Fertilizers are added to replenish soils. Kenya's tea growing regions are endowed with ideal climate; tropical, volcanic red soils; well distributed rainfall ranging between $1200 \mathrm{~mm}$ to $1400 \mathrm{~mm}$ per annum; and long sunny days (Tea Board of Kenya, 2010). Production of tea is done all round the year with two peak seasons of high crop between March and June and October and December, which coincide with the high rainfall seasons. Planting materials are done through vegetative propagation of high-yielding, well adapted clones (Tea Board of Kenya, 2011).

Tea Research Foundation of Kenya has developed over 45 varieties of tea (Tea Board of Kenya, 2011). Farmers pluck two leaves and a bud and young shoots are plucked at regular cycles ranging from 7 to 14 days. According to Tea Board of Kenya (2010) tea is grown in an area of over 157, 720 hectares, with production of about 345,817 metric tonnes annually out of which over 325, 533 metric tonnes are sold abroad.

\subsection{Tea Growing among Small Scale Farmers}

Nyangito (2001) defines small holder farmers as those who farm in less than eight hectares of tea farms. Small holder tea growing was allowed by law in 1963 (CPDA, 2008). By 2005, small holders had more acreage in tea, covering sixty six percent of the total area under the crop (Mwaura \& Muku, 2007). Latest statistics show that, approximately 62 percent of the total tea crop in Kenya is produced by more than 562,000 small-scale farmers (Daily Nation, Sunday 25 April 2010).

Smallholder farmers produce and sell their tea through the Kenya Tea Development Agency, which is the largest single tea agency in the globe with sixty two tea factories. The rest of tea is produced by large-scale tea plantations that operate thirty nine factories. A few of these large-scale tea firms include Unilever Tea, James Finlay, Kakuzi and George Williamson.

Small-scale tea farmers are generally price takers and sell their green leaf to collectors, plantations or processors (Chan et al., 2010). The main challenges in the small-scale tea sub sector include: low farm gate prices; poor extension services; limited marketing channels; poor access to credit and low level of farmers' organization (Chan et al., 2010). The cost of production for small-scale farms is lower than plantations because of concealed family costs and the fact that they do not bear social costs. Small holder farmers use family labor in planting, plucking and delivery to collection centers (buying centers). Chan et al. (2010) have noted that Kenya and Sri Lanka have become more productive on the global market because of increased smallholder production. However, Chan argues that the activities of smallholder farmers are less environmentally friendly and thus hard to incorporate them in export market supply chains that call for increased quality, social and environmental standards.

Tea industry in Kenya is similar to Japan in that smallholders contribute the biggest percentage of the output. It is different to Bangladesh where the majority of Tea fields are owned by companies, however, when it comes to selling tea, Bangladesh and Kenya are similar in that they use the auction system (Huque, 2007). 


\subsection{Tea Processing in Kenya}

Black and green teas are the two types of tea processed in Kenya. Currently, all Kenya Tea Development Agency factories are only processing black teas. Green tea is different from black tea because fermentation of green leaves is arrested in manufacturing green tea (Tea Board of Kenya, 2011). Kenyan tea has for many years been sold in its whole form, although in recent times the tea sector has been looking at the likelihood of selling tea extracts (Tea Board of Kenya, 2011). Tea is primarily processed using the Cut, Tear and Curl (CTC) technique to guarantee maximum cuppage per unit weight.

\subsection{Tea Performance and the Economy}

The tea industry contributes 4 percent of Kenya's Gross Domestic Product and 10 percent of Agricultural Gross Domestic Product (Tea Board of Kenya, 2009). The government of Kenya lists tea industry as one of the pillars of realizing the government's Vision 2030. Kenya's tea annual production is approximately 350 thousand tons, which is ten percent of the total world tea production. According to Tea Board of Kenya (2010) tea is not only the most important agricultural sub-sector, but also the second leading foreign exchange earner in Kenya after tourism, contributing about 26 percent of the total foreign exchange earnings. Writing on the same vein, Gesimba et al. (2005) noted that tea industry employs approximately 10 percent of the Kenyan population.

Comparing tea farmers' assets with the non tea farmers, Simbua, and Loconto (2010) showed that farmers involved in tea production own relatively bigger stocks of household assets compared to non-tea households. There is also evidence that households with larger stocks and better flows of assets tend to perform better, in terms of green leaf yields, than those with smaller asset bases. Tea production is associated with accumulation of assets. Thus, it can be concluded that involvement in tea production improves the quality of life of rural families. In addition, tea in Kenya is grown and partially processed in rural areas thus contributing considerably to the growth of rural infrastructure. Tea also enhances the wellbeing of communities living in rural areas.

\section{Export Performance Challenges of Kenyan Tea}

According to Central Bureau of Statistics (2005) tea contributes twenty eight percent of the value of Kenya's total agricultural exports. The major customers of Kenyan tea are Pakistan, the United Kingdom, Egypt and Yemen, who account for seventy percent of Kenya tea export (Chan, et al., 2009). Pakistan on its own buys twenty three percent of the total tea export (EPZA, 2005).

One of the challenges of tea exports is over dependence on a small number of key export markets (Chan et al., 2009). The danger of over reliance on a few markets was demonstrated in 2008 by Pakistan decision to reduce tea imports from Kenya. During this time, Kenyan tea export shrunk to 80 million in 2007 from 98 million in 2005. Chan et al., (2009) attributes this decrease to Pakistan entry into Free Trade Agreement (FTA) with India and Sri Lanka as part of the South Asian Association for Regional Cooperation (SAARC). In addition, the danger of over reliance of few export markets is also illustrated by Egypt political crisis of February 2011, when the prices of tea fell from $\$ 3.28$ for a kilo of grade 1 tea to $\$ 2.99$ (Daily Nation, 2011). Egypt has a market share of 21 percent of Kenyan tea.

Another challenge is that Kenyan tea (from small scale farmers) is mainly exported in semi-processed form to produce some of the well known global tea brands. According to Nyangito and Kimura (1999), Kenya's tea plays a very important role in blending with other teas to improve their quality. Value addition of Kenyan tea exports is minimal. The key players in the world tea exports like United Kingdom and Germany are not tea producers themselves but generate up to fifty percent of Kenya tea export earnings through value addition (FAOSTAT, 2008). Thus, the limited value addition and high costs of production makes tea export from Kenya less competitive in world markets (Chan et al., 2009).

\section{Organizational Structure of Tea Industry in Kenya}

The government Sessional paper No 2 of 1999 on the liberalization and restructuring of tea industry in Kenya provides a desirable organizational structure of tea industry. The Ministry of Agriculture is charged with the role of decision making in the whole sector. The tea sector is organized with diverse players having different roles that complement each other. The sector is structured into regulatory, research, producers, traders and value addition operations (EPZA, 2005). Figure 1 shows the organizational structure of the tea industry in Kenya. It depicts the tea supply chain comprising a web of actors ranging from regulators, agencies, producers, collectors, traders/brokers and packers. The following is a description of these players.

Ministry of Agriculture- This is a government ministry responsible for promoting and assisting in the production of food and agricultural raw materials (tea included) for food security and incomes. In addition the ministry 
promotes advancement of agro-based industries and agricultural exports and sustainable use of land resources as basis for agricultural ventures.

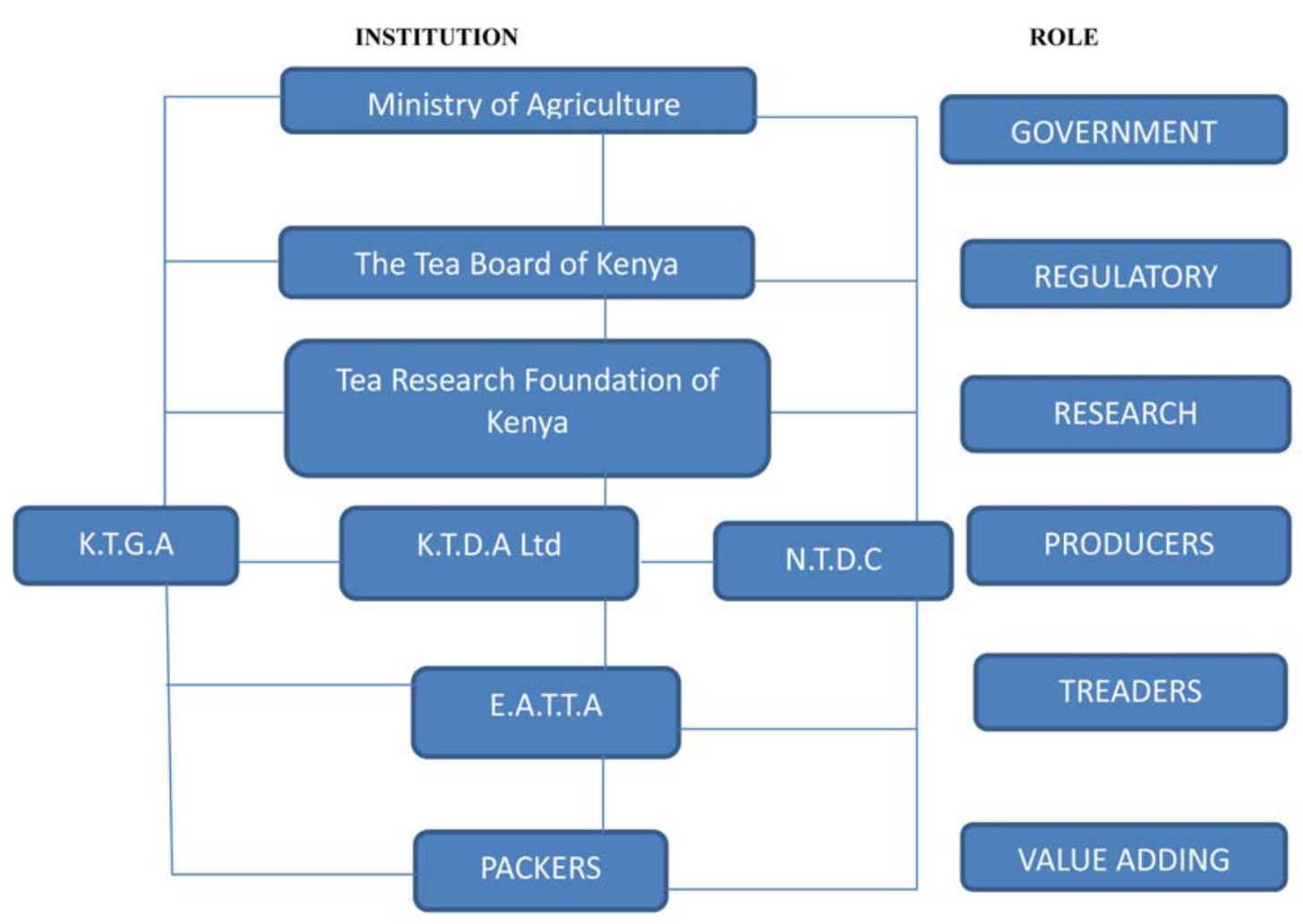

Figure 1. Organizational structure of the tea industry in Kenya

Source: Tea Board of Kenya (2004)

The Tea Board of Kenya- This body was founded in 1950 under the Tea Act (Cap 343) of Kenyan laws. Its mandate is to regulate the tea industry in the areas of tea growing, research, processing, trade and promotion in local and global markets. In addition, it disseminates information related to tea and advices the government on all policy matters related to the tea industry through the ministry of agriculture (Tea Board of Kenya, 2011). Specifically, the Board regulates and controls the farming of tea and registers tea growers and management agents. It also licenses tea processing factories and controls the techniques of tea processing. To date the Board has licensed 62 small holder-owned factories managed by Kenya Tea Development Agency Ltd and 39 private estate companies. When licensing it ensures that the new manufacturer has more than 250 hectares of mature tea bushes to run the factory (Tea Board of Kenya, 2011).

Tea Research Foundation of Kenya- This is the technical arm of Tea Board of Kenya and is located at Kericho, in the Western part of Rift Valley. According to Tea Board of Kenya (2011) the mandate of Tea Research Foundation of Kenya is to carry out research on tea and advice farmers on control of pests and diseases, improvement of planting material, general husbandry, yields and quality. In addition the Foundation provides advisory services to the growers on specific problems encountered in tea growing through organized field visits, demonstrations, and publication of research findings and reports. Tea Research Foundation has developed and released to growers over 45 well adapted clones of tea.

Kenya Tea Development Authority (KTDA) Ltd- KTDA started as Special Crops Development Authority in 1963 but was changed to KTDA in 1964. It was registered as private company in June 2000 under Cap 486 of Kenyan laws. It is the management agency of the smallholder sector farmers. It is currently managing sixty two tea factories in the small scale tea sector serving over five hundred thousand growers. KTDA functions include factory unit management and support services, sales and marketing, financial services and tea management and 
consultancy services (KTDA, 2011). It also provides extension services, production inputs, green leaf collection, processing and marketing of processed tea on behalf of small scale tea farmers (KTDA, 2011).

Nyayo Tea Development Corporation (NTDC)- This is a government corporation founded to manage the tea belts around the forest zones planted to create buffer zones meant to protect the natural forests from human encroachment (Tea Board of Kenya, 2011).

Kenya Tea Growers Association (KTGA) - This is an organization of large scale tea producers that was founded by large scale tea producers. Its goals include promoting the common interests of the members in the growing and manufacturing of tea by encouraging good industrial relations and sound wages policies for the workers in factories (Tea Board of Kenya, 2011). Recently it has been involved in confrontation with trade unions in the tea sector over the introduction of plucking machines that are likely to displace many tea pickers. The large scale (plantation) sub-sector has thirty nine tea factories (Tea Board of Kenya, 2011). The main players are multinational tea companies like Unilever Tea, James Finlay, and Williamson Tea, among others.

East African Tea Trade Association (EATTA) - This is an organization of tea producers, brokers, buyers and packers. The Mombasa Tea Auction is conducted under this association (Tea Board of Kenya, 2011).

Tea Buyers- These are persons or companies that buy tea for export or local purposes. The tea buyers operate through local agents.

Tea Packers and Blenders- The tea packers and blenders blend and pack tea as household brands as well for corporate consumer chains.

Tea SACCOS- These are Tea Saving and Credit Cooperative Societies. They provide financial services (such as loans, saving facilities) to tea grower members. Recently, they have started to recruit non-tea growers as members.

Tea Brokers- Tea brokers facilitate the sale of tea on the behalf of producers. There are 12 registered companies who operate as Tea brokers at Mombasa Tea Auction. To apply to EATTA, they are required to have good financial standing. They are required to provide bank guarantees as security to tea placed for sale. In addition, they are required to be independent and impartial. Their primary functions are: tasting tea for the purpose of quality verification; determining the best price for respective qualities of tea; liaising with warehouses to ensure that tea is received, handled and stored in a professional manner; and addressing concerns from buyers as to quality and quantity of tea purchased.

Tea Factories- There are 62 KTDA managed factories in Kenya (Tea Board of Kenya, 2010). They process green leaf collected from the farmers.

\section{Challenges Facing Small Scale Tea Farmers in Kenya}

The challenges facing small scale Kenyan tea farmers can be categorized into five: 1) production related challenges; 2) management agency challenges; 3) local market related challenges; 4) regulatory challenges; and 5) international market related challenges.

\subsection{Production Related Challenges}

The production related challenges include old tea gardens, low quality of tea, drought and climate changes, poor workers and employee relationships, lack of labor and high costs of labor, high costs of inputs and other operational costs, poor access to information, lack of training, use of child labor, marginalization of women in sharing of tea income, protection of wildlife, pollution of water catchments areas, planting of eucalyptus trees in water catchments areas, safety and health of workers, and farmers' representation.

a) Old tea gardens- In Kenya, most tea gardens are over 30 years old and past their most productive age. Some 1950s tea gardens are still intact. Replacements of these old gardens with new varieties could bring about considerable gains. Huque (2007) showed that mature and young bushes are more productive than old bushes and it would be advantageous if farmers were to continuously replace the old bushes. Huque observed that with adoption of young tea bushes production can be increased by $3,818 \mathrm{~kg} /$ hectare all other things held constant.

Although, the Tea Research Foundation in Kenya has developed 45 tea varieties, farmers have not adopted them because tea as tree crop has a long gestation period (roughly 3-5 years). In addition, the cost of planting tea to maturity is huge, making it difficult for farmers to adopt new varieties. There is also a problem of information dissemination whereby many farmers may not be aware of new varieties of tea. Adoption of new varieties by farmers may be achieved if the supply chain management practices (discussed later in the paper) are adopted. Tea Research Foundation would also play a great role in encouraging farmers to adopt new varieties that are more productive. 
b) Low quality tea- Farmers in Kenya have specialized in production of bulk undifferentiated tea with focus on volume rather than quality. The Export Processing Zones Authority has noted that value addition remain the major investment opportunity for the tea sector in the country (EPZA, 2005). On the same vein, Agri-food Consulting International (2004) notes that for tea sector to be a driver of rural growth, interventions in the sector must address the means of raising quality in the value chain. This can be done by adopting improved varieties of tea. However the adoption is hindered by high costs of inputs and long gestation period of tea. Other measures of improving quality include applying right amount of fertilizer, application of manure and plucking methods.

c) Drought and climate change- Drought is a major climatic change effect/factor and a challenge facing tea industry in Kenya. Like most other agricultural crops, small holder tea depends on rain fed agriculture. In times of drought production drops by very huge margins causing a lot of misery especially to small holder farmers. For instance, droughts in the years 1997 and 2000 forced production to slip by about 15 percent. The drought of the year 2000 was even worse whereby tea farms were badly scorched. In 2006, Unilever Tea Company which controls the largest plantations in Kenya, temporarily closed three of its eight factories and run the others at a reduced capacity because of reduced output as a result of drought.

d) Poor workers-employee relationship has also affected the tea sector. Although this may not be a big problem among the micro scale tea farmers since most labor is provided by family members, a number of small scale tea farmers (with more than 10 acres) do experience the challenge. This happens when these farmers cannot get laborers to pick their tea and therefore tea plants overgrow, leading to losses. In addition, tea pickers have been coalescing with the objective of agitating for higher payments. In some places the pickers have managed to force small scale farmers to pay Ksh. 8 (\$ 0.1) per kilogram of green leaf plucked. It is also important to note that tea farmers are paid Ksh. 12 (\$0.15) per kilogram of green leaf for monthly payments. This however excludes annual payments (roughly $\$ 0.5$ per kilogram), commonly referred to as bonus. Tea pickers' agitations for better payments have led to tea pickers and farmers having poor working relationships. Traditionally, workers agitation for higher payments has been concentrated in plantations and current developments among small holders are surprising.

e) Lack of and high costs of labor- This is a challenge to small scale farmers with over 10 acres of land whereby they may lack workers to pick their tea. Non-availability of tea pluckers has pushed the tea plucking's average kilogram payment from Ksh. 5 (\$ 0.06) in 2008 to Ksh 5.50 (\$0.06) in 2009 to Ksh 6.00 (\$ 0.07) to Ksh. 7.00 (\$0.08) in 2010 and Ksh. 8 (\$0.09) in 2012. It is important to note that at the time of writing this paper, farmers were paid Ksh, 12 (\$ 0.15) per kilogram monthly by Kenya Tea Development Agency. This implies that the tea pluckers take more than half of what the farmer is paid per month. This trend of labor shortage had however been predicted by the intergovernmental group on tea export consultation on tea market issues in 2002, that despite the projected tea production expansion in Africa and Far East, there was potential labor shortage for Africa due to HIV/AIDs pandemic (Thomas Jefferson Auditorium, 2002).

Other reasons contributing to labor shortage in tea growing areas are rural urban migration and young people negative perception towards employment in agricultural sector. To ensure sustainability in availability of labor the government needs to improve the general conditions in rural areas by providing social amenities, improving roads and communications infrastructure, and providing electricity among many others. It is also important to emphasize the importance of agriculture in economic development right from the time the child enters primary school. It is worrying to note that agriculture is not an examinable subject among schools in Kenya.

f) High costs of inputs and other operational costs- The cost of fertilizer, the major input, is very high making the cost of production enormous. In 2009, the average price of 50 kilogram bag of fertilizer was Ksh. 1836 (USD 23) compared to Ksh. 1296 (USD 17) in 2007. The other operational costs are the costs of weeding, pruning and plucking.

According to CPDA (2008) the cost of tea production in Kenya is USD 1.33 per Kg, and this compares poorly with other countries such as Vietnam (USD 0.81 per $\mathrm{Kg}$ ) as well as its neighbours in East Africa community; Rwanda (USD 1.32 per Kg, Uganda (USD 1.20per Kg) and Tanzania (USD 1.16 per Kg).

g) Poor access to information- Small holder farmers have lacked information on better tea farming methods since the tea sector was liberalized in 1990s. During the days of government control of the sector, farmers used to get extension services (including information on better tea farming practices) from the Ministry of Agriculture. After liberalization, farmers are required to pay for these services, which most are unable to pay or they are ignorant about their usefulness. As noted earlier, Tea Research Foundation of Kenya has developed 45 varieties of tea but many farmers are yet to adopt them due lack of information about their availability. 
According to CPDA (2008) the information flow is poor and at times lacking, especially that relating to pricing. Further, farmers at the bottom of the pyramid are the most disadvantaged, as they receive little information and their feedback hardly reaches the top; and when it gets there it is misrepresented.

h) Lack of training- Small holder farmers lack general farm management practices. Study by Mwaura and Muku (2007) indicated that small scale tea farmers had diverse experience in tea farming, ranging from one year to fifty years, affecting productivity. They further noted that some tea farmers failed to use any fertilizer on their farms, while others used more than the recommended quantity of $150 \mathrm{~kg}$ of nitrogen per hectare per year and used $494 \mathrm{~kg}$ of nitrogen per hectare per year. Poor supervision of tea pluckers and other farm laborers contributes significantly to high operational costs.

i) Use of child labor-The use of child labor in tea industry is mainly restricted to the use of family children labor. This is where families use their children in plucking tea or weeding especially after school (on Saturdays or during school holidays). The use of paid child labor used to exist in 1980s and 1990s but was discouraged by the government and civil society groups and has since been reduced to very minimal levels. The other kind of child labor is where the paid adult workers use their children in plucking or weeding tea gardens. These forms of child labor should be discouraged as they are violation of children rights. Child labor denies children right of obtaining education thus confining an entire generation to poverty.

KTDA should develop a program of educating small holder farmers on the dangers of child labor. Small holder farmers should be made to know that global media attention on the use of child labor in tea industry will lead to denial of entry of Kenyan tea exports in some markets such as those in Europe and North America where human rights are now considered as criteria in trade. Thus, to ensure sustainability of small holder tea sector in Kenya child labor must be discouraged.

j) Marginalization of women in sharing of tea income- One of the unique features of African agriculture is that women customarily specialize in the production of food crops (maize, bananas, beans) while men on commercial crops like tea and coffee. In addition, women do not own land. It also important to note that in the small holder tea sector in Kenya, majority of tea pluckers are women. However, the income from tea is taken by men who are the owners of land. With the global trend toward empowerment of women it is important that this marginalization of women in sharing of income from the tea sector be reversed. This will be one way of ensuring sustainability of the small holder tea sector in Kenya since women rights are now regarded as criteria for trade in some countries. Violations of women rights might lead to denied entry of Kenyan tea in some export markets.

k) Protection of wildlife- Small holder tea farming in Kenya is undertaken in areas close to rain forests with a lot of wildlife. As a result of farmers clearing land for tea cultivation wildlife are now confined to protected government forests. There is less wildlife in uncultivated land outside government forests mainly because of hunting activities by the farmers. In addition, hunting activities are also undertaken in government forests. Rain Forest Alliance is one of the international civil society groups that are discouraging tea farmers from hunting of wildlife in farmers owned forests or government protected forests. Hunting animals for meat or other purposes has the danger of killing some of the endangered species of animals.

Protection of wildlife is a major issue globally and farmers must be educated on this matter. Failure to protect wildlife may lead to Kenyan tea being denied entry in some markets as protection of wildlife is now regarded as an issue in trade. Therefore, to ensure sustainability of the small holder tea sector in Kenya farmers must be educated on the consequences of continued hunting of wildlife in their farms or government protected forests.

l) Pollution of water catchments areas- Small holder tea farming is concentrated in major water catchments areas of Kenya. One major concern in these areas is the effect of farming activities on the quality of water. This is especially so when you consider the farmers' use of chemical fertilizers and other chemicals which are washed into rivers during rainy seasons. Other ways in which rivers are polluted is through washing of automobiles near rivers. Rain Forest Alliance is working with KTDA to educate farmers on methods of preventing water pollution in these water catchments areas. Since water pollution is one of the major global concerns small holder farmers would be better advised to protect water from pollution as failure to do this will lead to Kenyan tea being denied entry in some international markets.

m) Planting of Eucalyptus trees in water catchments areas- This is one of the major trends in areas where small holder tea farming is practiced in Kenya. Majority of farmers have started to grow Eucalyptus trees for firewood and commercial purposes. This trend has been encouraged by KTDA that uses these trees to provide wood fuel in tea processing. Environmentalists have been critical of planting of Eucalyptus trees in water catchments areas (where many of these trees have been planted) as they are said to be major consumers of water. According to environmentalists, where these trees have been planted rivers have dried up and this is the major reason they are 
using to discourage Eucalyptus planting. Considering that environmentalists tend to catch the eye of the media it is important for KTDA to educate farmers from planting these trees in water catchments areas. These will help to ensure the sustainability of the small holder tea sector in Kenya. Negative publicity globally will lead to Kenyan tea being denied entry in those markets where environmental standards are adhered to in trade.

n) Safety and health of workers- This is another workplace issue that is being taken with a lot of seriousness globally and which small holder farmers and management of KTDA tea factories must consider in their practices. Small holder farmers should provide tea workers with protective clothing like rain coats and gum boots. Similarly, people working in KTDA managed factories should be provided with safety and protective clothing. Their work places should also be safe and healthy. In addition, they should be provided with medical insurance cover and other types of insurance that will guarantee them safety and health security. Small holder farmers can also jointly provide their workers with insurance cover and this can be done through deductions made at KTDA. This is necessary and important as it will ensure that those working in the sector are guaranteed their safety and health. It will also ensure sustainability of the small holder tea sector in Kenya. Workers issues are human right issues which should be considered as standards that must be adhered to in global trade.

o) Farmer representation- Small scale tea farmers are not well represented in KTDA, TBK and EATTA, or their representatives are compromised (CPDA, 2008). The directors who are meant to represent farmers are largely ineffective or compromised and the elections are highly politicized. Relationship between farmers and their factories need to be strengthened, so as to increase ownership and their participation, this is important so that farmers can stop feeling disfranchised. Farmers associations need to be strengthened. Kenya Union of Small Scale Tea Owners (KUSSTO) which has mandate to operate in the whole country has not been effective due to interference and vested interests and its presence and activities has been restricted (CPDA, 2008).

\subsection{Management Agency Challenges}

The KTDA as a management agency is faced by various challenges which include:

a) Administrative challenges- They include poor coordination of KTDA's operations, unreliable and inconsistent leaf collection and processing leading to significant losses and wastage in the supply chain and lack of transparency and accountability in the procurement system of inputs. Poor coordination of KTDA's operations can be tackled through investment in information technology to ensure accessibility of information by various parties in the supply chain. Unreliable and inconsistent leaf collection and processing can be addressed through such measures as investment in more trucks, implementing a schedule for leaf collection and improving capacity in tea factories. Improving roads in tea growing areas can also help to sort out this problem. This is because poor roads worsen the problem of green leaf collection. Lack of transparency and accountability in the procurement system of inputs problem can be solved through opening tendering methods. The tenders should be advertised in major dailies in Kenya and the tenders should be opened in public where all those who have tendered are present. Such practices will ensure sustainability of the small scale tea sector.

b) The poor roads infrastructure- Plucked tea is usually collected from the various tea buying centers by the KTDA trucks. The poor road infrastructure, affects the ability of tea farmers to meet the required processing schedules contributing to a lot of tea wastage. To ensure sustainability of the sector farmers should come together and improve the quality of these roads. For instance, farmers can have a communal work day when they can dedicate the time in unblocking the drainage and repairing bad sections of the roads. Farmers should also be educated on the importance of electing effective directors to the tea factories boards. The elected directors manage the KTDA fund on roads improvement in respective tea growing areas. Since most of the elected directors are not effective it has resulted in improper use of these funds and thus poor roads.

c) Use of wood fuel- This is another challenge facing the tea sector in Kenya. Due to high cost of fuel and electricity, many KTDA tea factories in Kenya use wood fuel. The consequence of this practice has been environmental degradation. Cutting of trees for factories use is likely to affect the amount of rainfall in tea growing areas in the long run. Kenya Tea Development Agency should encourage tea farmers to implement wood fuel planting and harvesting policies. The factories should develop plant nurseries that they can provide farmers at reduced prices.

d) Factory inefficiencies- According to KTDA (2011), the challenges in the management of out-growers business include the ever-escalating labor costs, energy costs and operational overheads. Computerization could make a huge difference in operational efficiency. Therefore, out-grower management and tea value chain should be computerized and automated. Recent implementation of computerization at tea buying centers has started yielding fruits to farmers through greater production brought about by greater accountability and accurate records. This could further lead to reduction of operational costs, enhancing information sharing among all 
stakeholders (such as factory managers, farmers, regulator, and other value chain partners), and stock reconciliations.

e) Limited product line. As noted earlier KTDA managed factories produce only black tea. The factories should produce green tea which has demand in developed industrial nations. The demand of green tea is also increasing in Kenya and many large supermarkets have increased the shelf space for foreign sourced green tea brands.

\subsection{Local Market Related Challenges}

There are a number of local market- related challenges, which include:

a) Lack of value addition- In Kenya the majority of agricultural products are sold abroad as raw materials. Investment opportunities for value adding activities through processing and packaging for agricultural commodities have not been exploited to increase farm incomes and off-farm employment (Kimenyi, 2002). Nyangito (2001) has noted that value adding to a crop like tea can fetch up to six times more revenue than unpacked tea. Kenyan tea is sold in semi-processed form to exporters who use it to blend lower quality tea from other countries (Tea Board of Kenya, 2009). To ensure sustainability of the sector KTDA managed factories should diversify from production of only black tea and produce a variety of branded tea products. This will help to improve farmers' income and reduce poverty levels in tea growing areas of Kenya.

b) Tea hawking- According to Kegonde (2005), the tea sector in Kenya face challenges of tea hawking practices that are widespread in the West of Rift Valley tea growing region. This happens among the small scale farmers who prefer to sell their green leaves for immediate payment than wait for the monthly payment. This practice may be attributed to high poverty levels. The problem with tea hawking is that the farmer only gets the farm gate payment which is usually very low and misses out on the annual payment commonly called "bonus" that is usually high in price per kilogram. In Kenya, tea hawking is illegal because it leads to exploitation of the small holder farmer by the middlemen who normally buy tea leaves from farmers at very low prices and later resell the produce to large multinational tea firms. To ensure sustainability of small holder tea sector tea hawking should remain illegal and outlawed. Small holder tea should continue selling their tea through KTDA as this helps farmers to achieve enormous economies of scale leading to high farmers' incomes.

c) Low local consumption- Although the inter-governmental group on tea export consultation on tea market issues (Thomas Jefferson Auditorium, 2002) projected that consumption of tea in tea growing countries would grow by $2.1 \%$ per year, this may not have been realized in Kenya because generally the promotion of tea especially among the young generation is still low. Aggressive advertising, coupled with conviction messages of health and style of tea consumption is needed to ensure sustainability of small holder tea sector. In addition production of variety of tea based products will increase total demand of tea in the country. Gesimba et al. (2005) has further noted that elimination of value added tax (VAT) on tea can promote local consumption.

\subsection{Regulatory Challenges}

According to Tea Board of Kenya (2011), in Kenya tea producers are supposed to comply with the following legislations and standards:

(i) Environmental Management and Coordination Act 1999 on Production, Processing and Handling of Tea;

(ii) Occupational Safety and Health Act (OSHA), 2007 (Certificate of Registration of a Work Place);

(iii) The Food, Drug and Chemical Substances (Food Hygiene) Regulations (Cap 254) for the Factory and Factory Staff Handling Tea;

(iv) Kenya Standard - KS: 459; Standard for Potable Water;

(v) Kenya Standard - KS 40; Standard for Labeling of Pre-packaged foods;

(vi) Kenya Standard - KS 1927; Standard on Specifications for Tea Packets and Containers;

(vii) Kenya Standard - KS 1972; Standard on Bulk Packaging of Tea for Safety, Quality and Integrity;

(viii) Kenya Standard - KS 65; Standard on Black Tea-Specifications.

In addition, the Tea Board of Kenya encourages the tea factories to acquire the ISO certification standards in:

(i) ISO 9001: 2008 in Quality Management Systems;

(ii) ISO 22000 in Food Safety Management Systems; and

(iii) ISO 14000 in Environmental Management System. 
It is through compliance with these legislations that the small holder tea sector can be sustainable. Internationally, some of these standards especially those on environment are considered as criteria for market entry. Thus, KTDA factories should comply with these standards so that Kenyan tea can be able to access markets in developed industrial nations.

\subsection{International Market Related Challenges}

Many factors that pose as challenges in the international market include:

a) Fluctuation of tea prices- Like other agricultural products, tea prices keeps on fluctuating. For instance, in a study on the impact of changing tea prices on family income of small holders in Kenya, Nyaga and Doppler (2009) noted that the price paid to tea farmers at Githambo tea factory in 1999/2000 decreased from Ksh. 23.38 (\$ 0.3) to Ksh. 12.05 (\$ 0.15)). They also identified fluctuation of tea prices as a major problem affecting tea farmers. This is because it led to variation of family income prompting farmers to continuously adjust their way of life. If a family did not have another source of income, the tea price changes would be more devastating. Children would drop out of school, diseases would go untreated, family would incur debts and food ration would reduce among other problems (Nyaga \& Doppler, 2009). The problem of fluctuation of tea prices can be addressed through holding of buffer stock, keeping stabilization funds, value addition, quality improvement and diversification of markets among other measures. These measures will ensure sustainability of the tea sector in Kenya. Further, the negative effects of fluctuation in prices can be reduced through increased local consumption of tea.

b) International certifications- Tea exports require international certifications to access international markets and to fetch high prices. For instance, Rain Forest Alliance, an international non-governmental organization (NGO) awards certification to tea factories that have produced tea in an environmentally sustainable manner. Rain Forest Alliance requires that farmers protect the natural forests within their jurisdictions and plant indigenous trees to increase forest cover. It also requires farmers and factories to produce tea ethically by avoiding child labor and protecting the health of workers both at the farm and factory levels (KTDA, 2011). Momul Tea Company in Kericho West District (Kenya) was the first tea factory in the world to be awarded the Rain Forest Alliance certification award. The award can be re-applied every three years. Costs of certification and compliance to fair trade and other international standards that are incurred by smallholders are prohibitive and must be handled by a well organized smallholder association. For instance, producers pay an average of USD 4000 yearly for the fair-trade certifications. Some smallholder associations in Tanzania have failed to raise enough funds to continue to pay the certification fee (Simbua \& Loconto, 2010). Despite these challenges tea factories must acquire these certifications so that their tea can be able to access international markets. This is one of the ways of sustaining the tea sector that continues to rely on export markets.

c) Regional integration with trading partners. For instance, the move by East African Customs Union to introduce a common external tariff of 35\% for tea led to a trade war with Pakistan, which is the largest buyer of Kenyan tea. Pakistan threatened a retaliatory action if the tariff was not withdrawn (Kegonde, 2005). On another vein, although Kenya is a signatory of three major international and regional trade agreements (the AfricanCaribbean-Pacific Group $\{\mathrm{ACP}\}$, the European Union $\{\mathrm{EU}\}$, COMESA and the East African Community $\{E A C\})$ the fruits of this integration are yet to be fully yielded. For instance, the volume of tea traded within the COMESA region is relatively low compared to its large population. Further, in spite of the COMESA Free Trade Area (FTA) protocol, trade barriers continue to exist particularly tariff and non- tariff barriers between Egypt and Kenya (Thomas Jefferson Auditorium, 2002).

\section{Supply Chain Management Practices for Addressing Challenges in the Small Holder Tea Sector in Kenya}

According to Mentzer et al. (2001) supply chain is a set of three or more entities involved in the upstream and downstream flows of products, services, finances, and/or information from a source to a customer. Thus, supply chain management offers firms' a management philosophy to handle their activities and incorporate them with downstream and upstream partners as well as firm's internal supply chain. As earlier discussed small holder tea sector in Kenya has so many players who may benefit from the supply chain management practices. For instance, Tea Research Foundation of Kenya (TRFK) has developed 45 tea varieties but they are yet to reach the farmers. This indicates a loophole in the tea supply chain which should be closed through proper supply chain management practices.

According to Mentzer et al. (2001) the aim of supply chain management is to improve the performance of the whole supply chain. It seeks to improve competitive performance by close integration of internal functions within a firm and effectively connecting them with external operations of suppliers, customers and other channel 
members (Kim, 2006). Thus, in order to improve the performance of the Kenya small holder tea industry all the players should be closely integrated.

This paper proposes an adoption of some supply chain management practices in small holder tea sector in Kenya in order to address the main challenges facing the sector. The adoption of these practices will bring about competitiveness within the tea sector both locally and internationally. These practices include:

\section{1) Improving supplier and customer relationship}

Supplier and customer relationship can be defined as a set of firm's activities concerned with managing its relationships with customers and suppliers to improve customer satisfaction and synchronize supply chain activities with suppliers as well as leverage supplier's capability to deliver superior products to customers (Lazarevic et al., 2007). Involving suppliers in product development enables firms to make better use of their suppliers' capabilities and technology to deliver competitive products (Handfield \& Nichols, 1999). Joint planning with suppliers also results in inventory reduction, smoothing production, product quality and lead time reductions (Ansari et al., 1999).

In Kenya, KTDA established a micro-finance company (Greenland Fedha Ltd) to provide financial services to small holder farmers to enable them cut down on rising costs of farm inputs (KTDA, 2011). Provision of credit to growers who are suppliers of the key raw material will lead to production of high quality tea leading to enhanced customer satisfaction. The Rain Forest Alliance discussed earlier is another strategic partnership that can benefit both parties (suppliers and customers). Further, KTDA should identify and partner with appropriate organizations which can add value to small holder tea and thus, provide an efficient network for delivering value.

There ought to be a mechanism through which buyers and small-scale farmers develop a direct relationship, this would assist tea farmers to know what quality and quantity these buyers need, this can be made possible via unions or associations that need to be created or strengthened (CPDA, 2008).

\section{2) Value addition of Kenya tea}

Kenya Tea Development agency managed factories should aim at being market oriented by producing tea that consumers need. The agency should conduct marketing research in order to understand market requirements. The agency has been producing semi-processed tea instead of adding value to farmers produce resulting in low prices for the farmers. An analysis of the Sri Lanka tea export market, where there is significant value addition, shows that Kenya exported more tea in volume than Sri Lanka in 2009 by 15 percent but the Sri Lanka earned 76 percent more from its exports than Kenya did (East Africa Tea Trade Association, 2010). Sri Lanka also sells 61 percent of her tea in bulk and 39 percent in value added form (East Africa Tea Trade Association, 2010). Diversifications in the industry need also to be encouraged so as to induce good prices.

\section{3) Adoption of information technology as a facilitator}

The way people conduct business today has changed as a result of revolution in information technology (IT) and communications. Latest networking technologies have huge potential in business according to managers and academic researchers (Baourakis et al., 2002). According to Lazarevic et al. (2007), information technology (IT) is a major facilitator of effective supply chain management. Information technology provides firms with competitive advantage (Porter \& Miller, 1985). As supply chain span many organizations in delivering products to customers both upstream and downstream and many functional areas within the firm, information technology allows the firm to enhance communication and coordination of various value adding activities with their partners and between functions within their own operations (Lazarevic et al., 2007).

Tea industry in Kenya will benefit a great deal from adoption of information technology because its supply chain has so many actors as discussed earlier. Information technology will improve coordination among the parties encouraging efficiency and effectiveness. According to Lancioni et al., (2000) and Lee and Whang (2000) internet technology offers firms opportunities of reducing costs, increasing their flexibility, increasing their response time and improving customer services. As mentioned earlier, KTDA has already computerized its operations at tea buying centers and this has already started yielding dividends in terms of greater accountability and returns. Networking all the players within the tea supply chain through computerization would yield greater benefits in terms of information access, market access and in operational efficiency.

\section{4) Information sharing for seamless integration within tea sector}

Information sharing is a significant feature in achieving seamless integration in a supply chain (Lee \& Whang, 2000). Information sharing can bring many benefits to suppliers and buyers such as inventory reduction and low manufacturing costs while poor sharing of information across the supply chain may lead to poor coordination 
that results in high inventories, inaccurate forecasts, low utilization and high production costs. To facilitate coordination between many supply chain partners in the Kenya tea industry, information sharing is essential. The Ministry of Agriculture as the overall overseer of the industry should devise strategies for encouraging information sharing among the parties. Information can be shared through organizing joint consultative meetings, conferences, workshops, seminars, websites, and emails among many others. Information sharing may also bring other benefits to the tea industry such as increasing pricing transparency, real time information and leverage in supply negotiations.

\section{5) Flexibility in internal operations/processes}

Internal operations refer to all activities associated to production systems and internal logistic flows (Lazarevic et al., 2007). Supply chain management requires flexibility in the production system as this enables the firm to respond to market needs. It also stresses the significance of both effectiveness and efficiency of company's internal operations on its performance. Poor internal operations can lead to failure in coordinating with external partners (Lazarevic et al., 2007). Order automation and factory automation are some of the key enablers to realize the benefits of quick response program. Firms should first integrate their internal functions before they can embark on integrating their activities with those of suppliers and customers. Kenya Tea Development Agency managed factories should improve their internal operations through automation of key processes. They should invest in computerization to ensure that tasks are conducted efficiently and effectively.

\section{6) Quality upgrading programme}

This involves improving the quality of the tea and the production process. Improving the quality of the product is especially necessary for poor farmers because importing countries have become quality conscious and new standards have been introduced in these countries. Therefore to compete in the global markets tea farmers need to improve the quality of their produce and the tea factories should modernize. The Tea Board of Kenya together with KTDA should set up a scheme for quality upgrading and product diversification. Low quality tea fetches low price especially where auction system is the mode of selling tea.

\section{7) Proper coordination among tea sector players}

If the different actors in the Kenya tea industry operate with proper coordination and consultation, this would have huge implications on quality control, competitiveness and bottom-line performance. As mentioned earlier, although Tea Research Foundation has developed 45 tea varieties they are yet to be adopted by farmers. Kenya Tea Development Agency that is supposed to ensure that farmers adopt these technologies has not been able to do so.

\section{8) Institutionalization}

There is lack of strong producer associations among tea farmers for watching over vital issues such as quality production of seeds, inputs provision to producers on credit, quality of inputs such as pesticides and extension services. With strong institutions clearly expediting their roles, the efficiency within the tea supply chain may be achieved.

\section{9) Policy reforms}

The tea industry in Kenya lacks policy on manpower development, dynamic technology development and regulatory and legal framework to operate in a liberalized market. The tea sector also seems to have been abruptly liberalized when KTDA factories were converted from state corporations to limited liability companies. Although nowadays farmers elect directors they were not given adequate education on how to conduct the exercise and majority of these directors have low levels of education (without degree certificates). Further, special efforts should be made to address the problems of small holder tea farmers, such as fixation of a price sharing formula between the farmer, the EATTA and other tea packers and blenders to enable the farmers to get a reasonable share of the tea price. The government should also implement a price subsidy scheme and special tea term loan package suitable for tea farmers. In addition, the government should consider reducing the tax burden on fertilizers.

\section{0) Training}

Successful implementation of competitive strategies largely depends on human assets of the tea sector. Effective competitive strategies require managers to have an understanding of supply chain dynamic and ability to use information based tools. Therefore, tea industry should think about the skills requirements and education when integrating its value addition activities with their partners. Training significantly contributes to improving supply chain management performance. According to Lazarevic et al. (2007) effective training and knowledge based 
learning is essential in developing and maintaining new supply chain management skills. Parties in the tea supply chain in Kenya should invest in human resource training and capacity building.

\section{1) Monitoring marketing environment}

This is important since it helps the firm to identify opportunities and threats facing the firm. According to Kotler (2003) a marketing opportunity is an area of buyer need and interest in which there is high probability that a firm can profitably satisfy that need. An environmental threat is a challenge posed by an unfavorable trend or development that leads, in absence of defensive marketing action, to deterioration of sales or profits (Kotler, 2003).

KTDA on behalf of the small holder farmers should continuously monitor the trends in the marketing environment with the objective of identifying marketing opportunities and threats. For instance KTDA, should be able to exploit such global opportunities as a trend towards a healthier lifestyle and greater emphasis on fitness. The firm should produce green tea that is regarded as having great health benefits. In addition it should promote the health benefits of taking tea. Similarly, to ensure sustainability of the sector the firm should identify threats that are likely to undermine the industry. Some of the threats facing sector include perception of use of child labor in tea plucking, use of chemical fertilizers, marginalization of women labor, use of wood fuel, pollution of water catchments areas, protection of wildlife, high cost of energy, labor and fertilizer, climate change, frost, and high consumption of cola products by young generation. It is important to note that some of these threats have global dimensions and failure to address them will lead to Kenyan tea being denied access in some global markets. It is imperative for KTDA to address problems relating to the use of child labor, marginalization of women in tea industry, use of wood fuel, and working conditions of tea workers among other issues that have international dimensions. By addressing these challenges KTDA will ensure sustainability of the small holder tea sector in Kenya.

\section{2) Strategic decisions}

In order to increase yield in poorly-managed farms, strategic decisions and value chain modification may be required as Huques (2007) proposed in Bangladesh and Japan. This can aim to enhance their yield, production as well as the quality of tea. Huques (2007) proposed the Japanese model, where cooperative farming is practiced among tea farmers. This can be replicated in Kenya, with modifications. Farmers should be encouraged to form strategic alliances among themselves in order to improve performance. Where such alliances are started, equipment and mechanization is possible which will end up saving cost and overcoming poor land management and plucking inefficiency.

\section{3) Irrigation}

Tea irrigation though not common in Kenya is gaining interest given the erratic weather conditions that most countries are experiencing. Tea irrigation has been noted to increase productivity and yield where it has been used (Kigalu et al., 2008; Moller and Weatherhead, 2007).

\section{4) Venturing in new markets through partnership}

Kenya needs to start shopping for new markets. Currently a greater proportion of Kenyan tea is exported to UK which makes it a powerful buyer that can easily dictate terms to the suppliers. Kenya Tea Packers, a subsidiary of KTDA has taken lead on this as noted by Gesimba et al. (2005). It has signed an agreement with Tabai tea of the USA which is earmarked to $10 \%$ of the market. When such strategies are pursued they will reduce over reliance on one market thereby cushioning farmers from erratic prices.

\section{5) Civil society involvement}

Looking at the supply chain of Kenyan tea industry it is evident that there is no civil society involvement. The fact that there is weak involvement by Civil Society Organizations (CSO) makes it difficult for NGOs to intervene on behalf of small-scale farmers (CPDA, 2008). Corporate social responsibilities need to be encouraged across the supply chain by all players. Tea companies and tea factories need to initiate activities that will benefit the surrounding tea growing communities (CPDA, 2008). Toward this end, a clear benchmark should be established that will serve as the basis for evaluating and monitoring the players. Presence of these organizations will facilitate exposing of malpractices thereby enhancing transparency as well as empowering stakeholders.

\section{Conclusion}

This paper provides background information on the small holder tea sector in Kenya; its performance and contribution to the economy; and categorizes specific challenges facing this sector. The Kenyan small holder tea 
sector has tremendous potential for growth and employment generation, if the relevant enabling steps to overcome the many challenges and inefficiencies are undertaken. This paper has provided various strategies to enhance competitiveness in this sector. Among these strategies are: supplier and customer relationships, value addition, information technology, information sharing, flexibility in internal operations/processes, upgrading tea seedlings, proper coordination, institutionalization, policy reforms, training and monitoring marketing environment. These strategies should be tested on the basis of their worthiness to overall small holder tea sector performance.

\section{References}

Agrifood Consulting International. (2004). Agricultural Consulting International Policy Brief Series. Retrieved from www.agrifoodconsulting.com

Ansari, A., Lockwood, D. L., \& Modarress, B. (1999). Supplier product integration: A New Competitive Approach. Production and Inventory Management Journal, 40(3), 57- 61.

Baourakis, G., Kourgiantakis, M., \& Migdalas, A. (2002). The impact of e-commerce on agro-food marketing: The case of agricultural cooperatives, firms and consumers in Crete. British Food Journal, 104(8), 580-590. http://dx.doi.org/10.1108/00070700210425976

Central Bureau of Statistics (CBS). (2005). Economic Survey 2005.

Central Business of Statistics (CBS). (2005). Nairobi, Kenya.

Chan, P., Marta A., Mihretu, M., \& Tamiru, K. (2010). Microeconomic of Competitiveness Country: Kenya Cluster: Tea.

Christian Partners Development Agency (CPDA). (2008). Report on Small-Scale Tea sector in Kenya. Retrieved from http://webcache.googleusercontent.com/search?q=cashe:5PAU2M521AJ:somo.nl/publication.

Daily Nation. (April 25, 2010).

Export Processing Zones Authority (EPZA). (2005). Tea and Coffee Industry in Kenya.

FOASTAT. (2008). Trade STAT. Rome, Italy: Food and Agriculture Organization of the United Nations. Retrieved from http://faostat.fao.org/site/406/default.aspx.

Gesimba, R. M., Langat, M. C., Liu, G., \& Wolukau, J. N. (2005). The Tea Industry in Kenya: Challenges and Positive Developments. Journal of Applied Sciences, 5(2), 334-336. http://dx.doi.org/10.1108/00070700210425976

Government of Kenya, The Tea Act (CAP 343), Legal Notice No. 132.

Handfield, R. B., \& Nichols, E. L. (1999). Introduction of Supply Chain Management. Prentice-Hall, Upper Saddle River, NJ.

Huque, R. (2007). Strategic Cost Management of tea Industry: Adoption of Japanese Tea Model in Developing Country Based on Value Chain Analysis. Retrieved from Kamome.lib.Ynu.ac.jp/dspace/.../1/4_Hique.pdf.

Kegonde, P. (2005). Economic Governance of the Tea Sector, A paper presented to CGD.

Kigalu, M., Kimambo. E., MSite, I. \& Gembe, M., (2008). Drip Irrigation of Tea (Camellia Sinensis L.): 1. Yield and Crop Water Productivity Responses to Irrigation. Agriculture Water Management, 9S(11), 1253-1260. http://dx.doi.org/10.1016/j.agwat.2008.05.004

Kim, S. W. (2006). Effects of Supply Chain Management Practices, Integration and Competition Capability on Performance. Supply Chain Management, 11(3), 241-248. http://dx.doi.org/10.1108/13598540610662149

Kimenyi, M. S. (2002). Agriculture, Economic Growth and Poverty Reduction. KIPPRA Occasional Paper No. 3, KIPPRA, Nairobi.

Kotler, P. (2003). Marketing Management (11th ed.). Prentice Hall of India Private Ltd.

Lancioni, R. A., Smith, M. F., \& Oliva, T. A. (2000). The Role of Internet in Supply Chain Management. Industrial Marketing Management, 29, 45-56. http://dx.doi.org/10.1016/S0019-8501(99)00111-X

Lazarevic, S. P., Sohal, A., \& Baihaqi, I. (2007). Supply Chain Management Practices and Supply Chain Performance in the Australian Manufacturing Industry. Monash University, Department of Management Working Series ISSN 1327-5216, Working Paper 21/07.

Lee, H. L., \& Whang, S. (2000). Information Sharing in a Supply Chain. International Journal of Technology Management, 20 (3), 373-387. http://dx.doi.org/10.1504/IJTM.2000.002867 
Mentzer, J. T., DeWitt, W., Keebler, J. S., Min, S., Nix, N. W., Smith, C. D., \& Zacharia, Z. G. (2001). Defining supply chain management. Journal of Business Logistics, 22(2), 1-25. http://dx.doi.org/10.1002/j.2158-1592.2001.tb00001.x

Moller, M., \& Weatherhead, E. K. (2007). Evaluating Drip Irrigation in Commercial Tea Production in Tanzania. Irrigation Drainage System, 21, 17-34. http://dx.doi.org/10.1007/s10795-006-9016-9

Mwaura, F., \& Muku, O. (2007). Tea Farming Enterprise Contribution to Smallholder' Well Being in Kenya. AAAE Conference Proceedings, 307-313.

Nyaga, E. K., \& Doppler, W. (2009). Use of Dynamic Models to Assess Impact of Changing Tea Prices on Family Income of Smallholders in Kenya. Journal of Applied Sciences, 9(9), 1647-1657. http://dx.doi.org/10.3923/jas.2009.1647.1657

Nyangito, H., \& Kimura, J. (1999). Provision of Agricultural services in a Liberalized Economy: The case of the Smallholder Tea Sector in Kenya. Kenya Institute of Policy Analysis and Research, Nairobi.

Nyangito, H. O. (2001). Policy and legal framework for the tea sub sector and the impact on the liberalization in Kenya. KIPPRA Policy Paper No.1, KIPPRA, Nairobi.

Porter, M. E., \& Miller, V. E. (1985). How information gives you competitive advantage. Harvard Business Review, July - August, 146-160.

Simbua, E. F., \& Loconto, A. M. (2010). Organizing Smallholder Production for Sustainability: Lessons Learned from Fair-trade Certification in the Tanzanian Tea Industry. Innovation and Sustainable Development in Agriculture and Food, Montpellier, 28-30.

Simbua, E., \& Loconto, A. (2010). Sustainability of Smallholder Tea Production in the United Republic of Tanzania. In Proceedings of Commodity Problems Intergovernmental Group on Tea Nineteenth Session, New Delhi, India, 12-14 Mau 2010. 26.

Tea and Coffee Industry in Kenya. (2005). Export Processing Zones Authority.

Tea News Briefs. (2010). The Monthly On-Line Newsletter of the Tea Board of Kenya- May 2010.

Tea News Magazine. (2010). A quarterly publication of the Tea Board of Kenya.

The East Africa Tea Trade Association. (2010). www.eatta.co.ke.

Thomas Jefferson Auditorium. (2002). Intergovernmental group on tea expert consultation on tea market issues. United States Department of Agriculture. 25 September, 2002.

http://www.teaboard.or.ke/

http://www.tearesearchkenya.org 